\title{
What Development Has Done to a Town: Lessons from Hambantota, Sri Lanka
}

\author{
Shalini Mariyathas, Nihal Perera, and Mohamed Yehiya
}

Hambantota, Sri Lanka was subjected to a massive transformation in the past decade (2005-2015). What used to be a town of 10,000 people, now has a harbor, an international airport (both second only to the one in the national capital Colombo), cricket stadium of the highest caliber. It is also the only city crossed by massive highways. No other town in Sri Lanka has transformed this significantly after independence. It is also a Municipal Council, which is considered the highest order city. This transformation was politically driven, since it is located in the district of the then President, Mahinda Rajapaksa (2005-2015), consequently there was no lack of funding and political will. It was the planners', development specialists', and building contractors' dream.

Yet what this change has produced is nowhere to be found; it has destroyed the sense of place but without a substantive replacement. The new town-center is represented in a welldesigned massive administration complex and an international convention hall built in the middle of nowhere. The highways dominate the landscape of nowhere.

It is worse for the ordinary inhabitants and visitors. The town is not only unfamiliar to them, but also disorienting. Hambantota can no longer be directly approached from Matara (Colombo), but the access is now rerouted to go around the port and the city. The former approach road to the city was lined by kaludodol (a local sweet) and meekiri (buffalo-curd) shops, many operating from houses. They are no more. The title "old town" has also been imposed on the town (Figure 1).

In short, the inhabitants of Hambantota are displaced. Many were involuntarily moved to the new town planned by the Urban
Development Authority (UDA). Some properties were forcefully demolished. Many businesses have disappeared, while most new jobs have gone to outsiders. From a people's perspective, Hambantota is a landscape of injustice and disaster. Much worse than the situation created by the tsunami; there is hardly a recognition that something is terribly wrong. In this sense, the inhabitants are subjected to slow violence. (Nixon 2013)

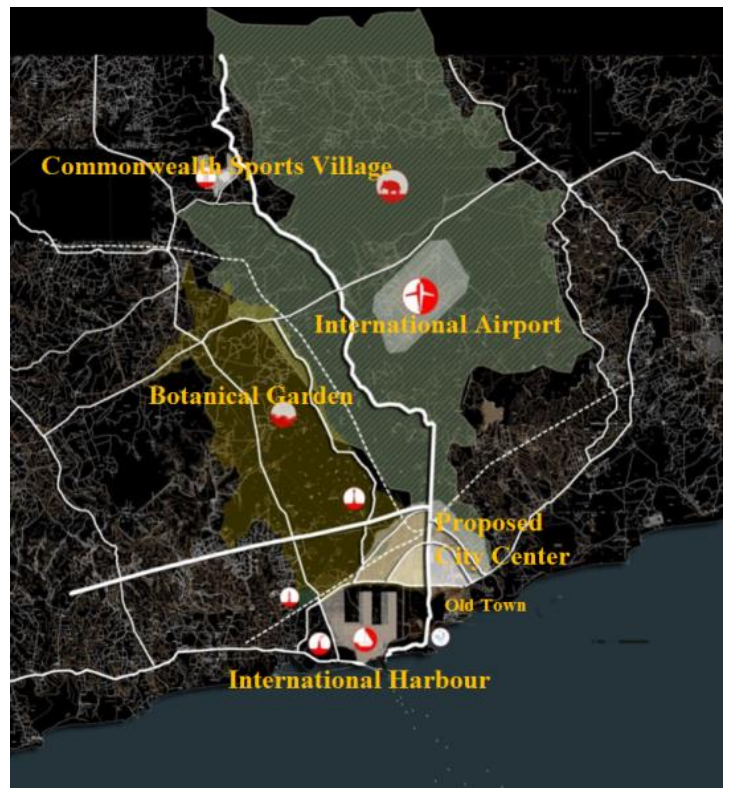

Figure 1: Major Projects of the Greater Hambantota Development Plan 2030 of Urban Development Authority. Source: Urban Development Authority

This paper is an attempt to make sense of this transformation from both planning and people's perspectives. The study is based on long-term fieldwork of different kinds, including observations, participant observations, ethnographies, interviews, long conversations, and teaching projects. ${ }^{i} \mathrm{We}$ will begin the paper by highlighting the characteristics of Hambantota as pertinent to the project. We will then map out the UDA 
proposal and investigate individual projects in groups. Finally, we will derive lessons.

\section{The Historical Port}

Hambantota is the major urban center in Hambantota District, located on the southern coast. We shall use Hambantota for the town/city and Hambantota District will be so called. The city is located $240 \mathrm{~km}$ from Colombo, by Galle Road. The new ColomboMatara highway has reduced the distance to $126 \mathrm{~km}$; the travel time has also dropped from five and a half hours to three and a half hours. For long-distance travelers who travel from Kataragama and Yala, Hambantota is the major urban center after Matara. Kataragama is a main place of pilgrimage in Sri Lanka and Yala is a wild life sanctuary. Many travelers used to stop and buy kaludodol and meekiri specific to Hambantota. However, the quick arrival due to the Colombo-Matara highway and the road structure that bypasses the city has deemphasized Hambantota. (Figure 2)

The district is also one of the two most arid areas in the country, which does not attract many rural migrants. In 2001, the whole district $(113,200$ ha) had a population of 206,588; with a density of less than two people per hectare, it is one of the lowest in the country. With only 11,200 living in the municipal area, which is also not heavily urbanized, the population of the district is overwhelmingly "rural." The region possesses many environmentally sensitive areas that include dry zone forests, reservoirs, ponds, bird habitats, and salt pans.
Prior to the new plan, the city did not possess a high-level economic engine, and the plan made no accommodation for a safe and viable one. People were engaged in fishing, agriculture, salt production, and services. It is most known for kaludodol, meekiri, and salt; Hambantota has one of the two main salterns of the country where salt is produced. People are also engaged in pottery and brick-making. Hambantota is diverse; it accommodates many different ethnic communities, the largest being Sinhalese and Muslim communities. It is home to Sri-Lankan Malays. The dominant national classifications lump them with other Muslims, making one homogenous ethnic group of Muslims. (Perera 1999) The level of coexistence among different people groups in Hambantota is quite uncommon in Sri Lanka. It is one among few places where the 1983 riots (or latter Sinhala-Muslim riots) did not occur. However, it is changing with new migrants.

Salt and Muslims are key to the history and identity of Hambantota. The city was historically known for the extraction and distribution of salt to the rest of the island. Before the advent of Europeans, Muslims held a monopoly on the internal trade of salt and the external trade in spices. Muslim traders took salt to the interior hill country and bartered it for spices, which they exported. Some researchers have documented the development of Muslim communities along this salt route.

As a diverse historic place, Hambantota's history is contested, so is its name. Some

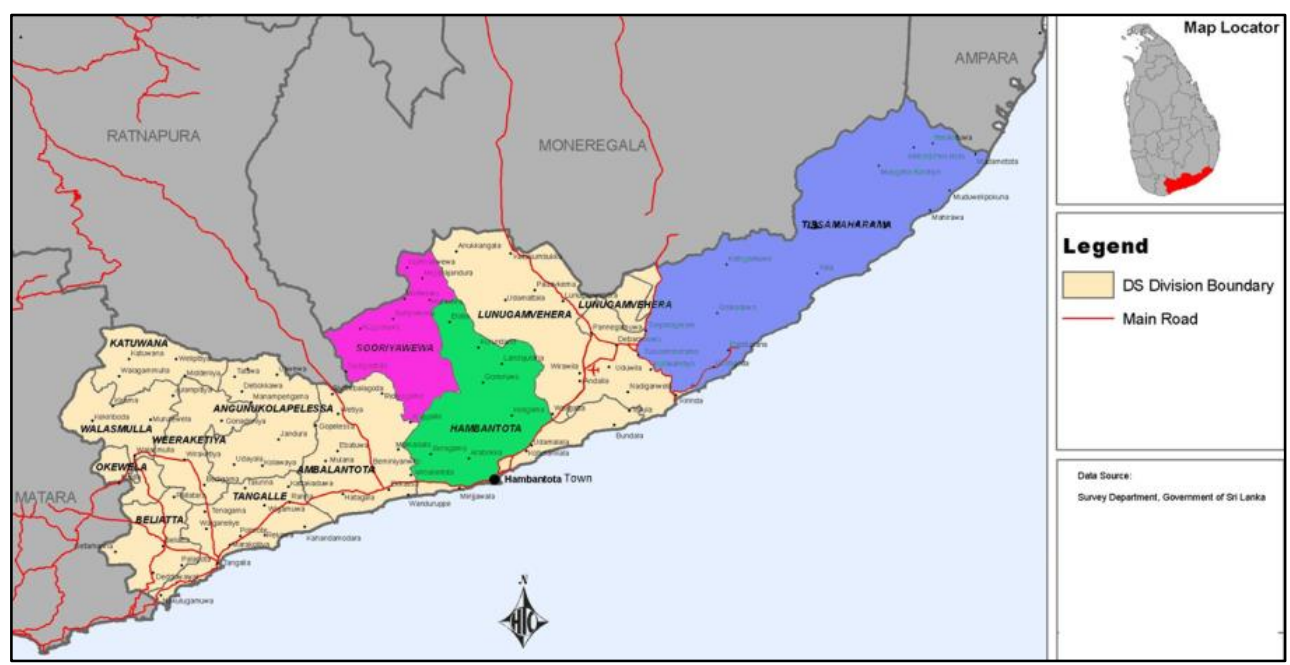

Figure 2: Location of Hambantota Town in the District Map 
historians highlight that the kingdom of Ruhuna in the south, including Hambantota, was established by King Devanampiyatissa of Anuradhapura in 200 BC. (de Silva, 1989) Regardless of the exact story, the region has been key to the Buddhist culture. The existence of a large number of historic temples provides testimony to this. Hambantota is also a significant place for Muslims and the Malay settlement also has a long history in the area. The community was large enough to maintain the language, which is spoken until today, but with particular localizations. The harbor, currently the fisheries harbor, also attracted travelers and traders from the Far East, Siam, China, and Indonesia.

Today's Hambantota, according to Charitha Ratwatta (2013), was built by the British. Being in the proximity of Galle harbor, located in an arid area, Hambantota was hardly attractive for the Portuguese and the Dutch. The oral histories of the residents indicate that the urban center was first established by Muslim (or Pre-Muslim) traders. The Portuguese who stationed a regiment at Hambantota in the sixteenth century possibly expelled the Muslims as they did in other ports. The Dutch too stationed a battalion, but to control the Muslim business and the salt supply to the Kandy Kingdom.

The British moved the garrison to Hambantota and, although quite small, built their own administrative city around the harbor. They expanded the port ${ }^{\mathrm{ii}}$ and also built a naval center. The administrative center included the Kachcheri (Government Agent's Office), regional administrative offices, schools, a police station, a hospital, and a court complex. (Ratwatta, 2013)

National governments hardly paid attention to Hambantota and the district experienced a decline. By the 1980s, Hambantota was considered the country's most remote and poorest region. The only industries of any capacity were salt extraction and dairy production. (Ratwatta, 2013) In 2000, 31\% of the population lived below the poverty line.

According to local newspapers, in 2008, the government announced that poverty alleviation programs have reduced poverty to $12.7 \%$. A majority of the inhabitants managed a livelihood at subsistence level, engaged in fishing, small-scale agriculture, and salt farming. The district was also one of the worst affected by the Indian Ocean tsunami of 2004. The official death toll is about 4,500. At this juncture, the fortunes of the city took a sharp turn in 2005. With the new President promoting his area, Hambantota received a huge place in the National Physical Plan 2030, finalized in 2011.

\section{The Turning Point: Power and Rationality}

Hambantota has gained huge importance nationally and internationally afterwards. In his political manifesto, Mahinda Chintana, the Presidential candidate Rajapaksa vowed to make Sri Lanka a Wonder of Asia. This vision was supposed to be materialized through the creation of five hubs: navigation, aviation, knowledge, energy, and commercial. The National Physical Plan 2030 incorporated these goals and opted to conserve the fragile central-region of the country and to more equitably distribute growth across five "metro regions" each with a metro city. The exPresident was also interested in serving Hambantota, thus granted the necessary political will, but the location of a national hub or a metro region in Hambantota has overwhelmed its inhabitants.

Transformations in Hambantota began during Rajapaksa's first term. First, Hambantota was designated one of the metro regions. Instead of mapping out the appropriate area, the planners renamed the District as the Greater Hambantota Metro Area with only $5.3 \%$ of the population is urban even in 2012 (Census 2012). Sri Lankan politicians and intellectuals have demonstrated an enormous inability to get out of the colonial thinking, especially in regard to maps and mapping. In regard to Hambantota too, the planner adopted the British administrative boundary demarcated for a very different purpose: ruling the colony. iii

The Greater Hambantota Development Plan 2030 was prepared by the UDA. The UDA's vision was to make Greater Hambantota a gateway to Asia. Combining Mahinda Chintana, it opted to establish five hubs. Regardless of the national significance, this resulted in mega scale projects such as Magampura International Harbour, Mattala 
International Airport, Commonwealth Games Village in Sooriyawewa, botanical garden in Mirijjiwella, and Hambantota city center in Siribopura.

The projects were portrayed (perhaps also viewed) as the steps towards a golden future for the town and its people. When the ideas met ground realities, private (power) demands won out against public needs and aspirations. Hambantota was, therefore, no different to Aalborg city in Denmark that Bent Flyvbjerg (1998) studied. According to Flyvbjerg (1998), although the basic idea of the Aalborg city plan was comprehensive, coherent, and innovative, and it was based on rational and democratic arguments, when idea met reality during implementation, the play of Nietzschean will to power, and Foucauldian rationality-as-rationalization resulted in the fragmentation of the project.

In Hamabantota, although the UDA took the lead, and provided scientific justifications for the development, the resultant projects are not the mere outcomes of this plan. The President and his inner circle were too keen to transform Hambantota. Many decisions were made politically leaving the UDA to justify. The directors of Hambantota UDA took upon the onerous role defending the outcomes to at least the abstract rational minded. As Flyvbjerg (1998, p.20) put it: "Decision First; Rationalization Later.”

Let us examine individual projects. We have grouped these according to their significance, role, and results for the better understanding.

\section{Emptying the City: Post-Tsunami Development}

The Indian Ocean tsunami of 2004 was a blessing for the planners and politicians who were on their mission. As Perera has experienced in many post-disaster discussions, including in Gujarat after the 2001 earthquake, Beirut after the civil war, Aceh after the 2004 tsunami, China after the 2008 earthquake, Joplin, Missouri after the largest tornado to hit America in 2011, the politicians, developers, planners, and policy makers saw a great opportunity to build a new, in a good way. Such achieving of their dreams immediately displaces what people have been building for decades, centuries, or even millennia. The professionals who know better assume a clean slate to build bypassing the difficult task of talking to people and taking them into consideration. This is precisely what the politicians, builders, developers, contractors, and planners did to people in Hambantota: bypass them and impose their views; the tsunami victims were used to populate the new town the UDA was building. The most helpless moment for the victims was transformed into the best time for politicians and planners to achieve their goals.

The government's response to the 2004tsunami was to not allow the rebuilding of any structures that were destroyed. This law was applied to an area within 100 meters from the sea. The rich whose structures were damaged were allowed to repair, but the poor, especially the fishermen, were evicted. This was the biggest land-grab after the Mudubim Panatha of the 1830s.

The UDA's role was to find relocation sites and these were four to five kilometers way from the sea (See Perera 2016). At Hambantota, the victims were directly incorporated into the new town project. The government and the politicians used the victims to get foreign funds, but used them to populate the UDA's new town. More houses than needed were built, even those who were displaced due to the harbor project were relocated. The neighborhoods in the new town now have name-boards such as Canberra Houses, John Keels Village, Care International Village, and Waraya Gama (gama meaning village).

Today, the resettled communities in the region are failing. Yet people are resilient and refuse to be victims, but rather survivors of two disasters: a tsunami and then the UDA. During our visits in 2008, the settlers were complaining that there is no new town and have no access to the present town. First, some tried to buy three-wheelers. People believe that the changes taking place around them increased their land value. Yet they do not have land titles to sell and leave. The UDA controlled their basic property. They understand the vulnerability that goes beyond 
selling: They think their land (with houses) maybe taken if the luxurious city center development needs them.

\section{Choking the Town: Port Development Blocking the Access}

The next disaster was the construction of the port in Hambantota. The harbor was planned as a service and industrial port. The government was more interested in creating a catalyst for major economic growth in Sri Lanka, but also expected to reduce unemployment in Hambantota region. This resulted in the closure of the approach road (CGMT Highway), freezing Mirijjawila Village. (Figure 3)

According to the Port Master Plan, thirty-three sea-faring vessels can be accommodated at a given time. It has been positioned as an industrial port with facilities to transship vehicles and provide bunkering services. The Hambantota Port will give access to traffic on one of the world's biggest East-West shipping lanes. The first two phases (2008-10; 2012-15) are now complete.

The port was a monster project and one intended to solve unemployment in a district of 200,000 people. It was a white elephant assertively pushed on the country. It is very Sri Lankan to build Asia's largest factories that neither produce much nor serve Sri Lanka much. These include the steel factory at
Oruwala, textile factory at Thulhiriya, sugar factory in Kantale, and the condensed milk factory in Polonnaruwa. School kids learned about these as great achievements under the umbrella of loken uthum rata (greatest country in the world). From the late-1970s, the governments switched to large-scale infrastructure projects with huge commissions. These large-scale projects belong to this genre. (See Perera, this volume).

The Sri Lanka Ports Authority periodically calls for proposals - both foreign and localto establish businesses within port premises. It has received proposals from investors in India, Pakistan, and Hong Kong. The proposed businesses include cement grinding, cement storage and bagging plant, fertilizer storage/processing bagging plant, liquid petroleum gas distribution facility, vehicle assembling plant, flour mills, food processing and packaging, and warehousing.

Yet the port has not been a great advantage for the town or its people. The dredged, inland harbor was located on Colombo-Hambantota road right before it enters the city center, after the Mirijewila neighborhood. It cut off the Colombo-Tissamaharama highway and blocked the main access to the town. The road closure and diversion removed a major reason for Hambantota's existence in the national map.

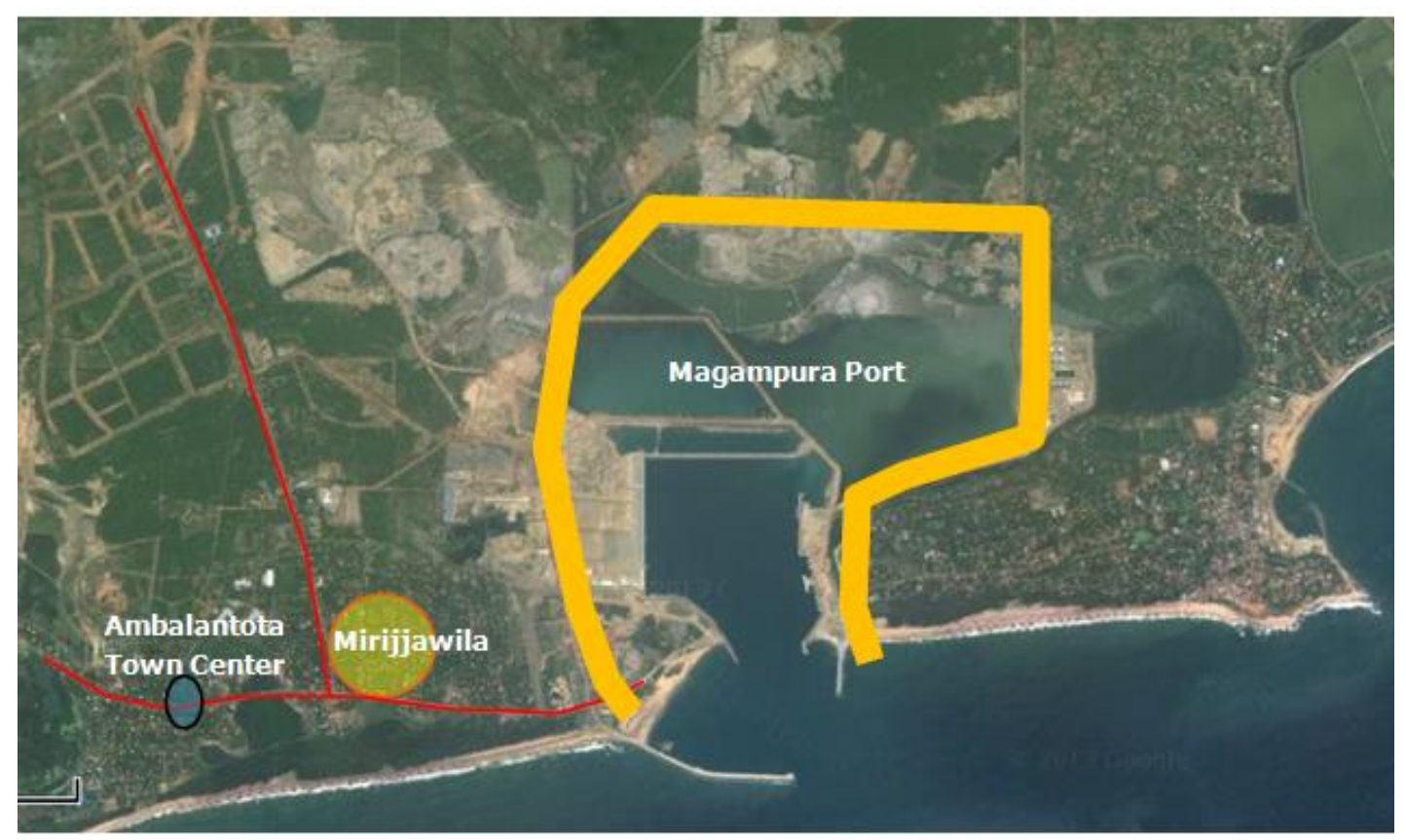

Figure 3: The Location of Mirijjawila Village, the Port Project and the Closure of CGMT Highway 
A large number of pilgrims who visit Buddhist sites and Kataragama Devale (Hindu temple) in vehicles stop at Hambantota as the last "big" town before the destination (i.e., after five or six hour of drive from Colombo). Many pilgrims and visitors enjoy the beach and the nearby town center. The activities intensify and business increases during Kataragama festival season (July/August).

The road was the major access to Hambantota itself from the Colombo side. The harbor now threatens to choke Hambantota. People have to go around the harbor and come back into the town. According to our study, seventy five percent of the businesses in the town center were closed due to the road closure.

This is not simply a loss of functions or a drop in numbers, but affects its identity and sense of place. Most significantly, Mirijjivila, the neighborhood on the west of the port is now cut off from Hambantota. Most of its residents now visit nearby Ambalantota, instead of Hambantota, for their groceries and commercial needs.

The main politicians in the government including the President, Speaker, the Secretary of Defense, and the President's sons were from Hambantota. They either did not care for a larger reason or had no knowledge of the implications of this project on Hambantota. So were the planners or planning scholars; they did not raise the issue either. The "experts" were busy with abstract thinking and securing their base, but not with the local impact.

\section{Pulling Apart: Airport and Cricket Stadium}

In addition to blocking, choking, bypassing, and starving select parts of the city, key activity centers, which bear the name Hambantota, were located far outside the city. We focus on two projects: the airport and the cricket stadium. By themselves these projects are of high quality. The airport is the second international airport of the country and the cricket stadium hosted world cup games. Instead of bringing the city together, these projects pull it apart; they suck its vitality. If successful, they amount to leapfrog development, critiqued in planning literature for decades.

The airport is located thirty to forty kilometers away from the city center. In contrast, Colombo airport is about twenty-five kilometers from the center of the city of 2,300,000 people and 3,729 ha. The whole Hambantota District has 200,000 people. Colombo Airport also serves the whole nation, not simply Colombo. Both the location and the scale are illogical for its scale and context.

According to our observations, Hambantota airport is tagged to the city; never conceived as a second national airport located at the most logical location on the island. When early studies failed to locate the airport at Weeravila, the protagonists never backed out; they continued until they found a location in Hambantota. The experts succeeded in justifying the project. Yet the city and the airport are far apart for a city of 10,000 people. Sri Lanka's territories are small; so are distances. Although brought closer by the highway, if successful, the hotels and other amenities that would support the airport and the industries and businesses that may follow would develop Mattala, sucking the life out of Hambantota.

The airport itself is quite underutilized. It serves two international flights per day operated by two airlines: Dubai Air and Rotana Jet. They both touch Colombo airport too and there is only one flight per week between Mattala and the national airport. This is insufficient to maintain the airport and to support the infrastructure. Planners and designers have missed both the geographic and economic scales.

The cricket stadium at Sooriyawewa, thirtyfive kilometers from the city, has similar implications. The stadium where 2011 World Cup matches were played is massive. It is impractical to get foreign teams (and the local team) to lodge thirty-five kilometers away from the field, at Hambantota. As in regard to the airport, the amenities that the park requires could conglomerate into a small town, or a handiya near the stadium. 
Yet, there are so few matches played, a service infrastructure is impossible. After building the stadiums for the world cup, the government could not afford to support the national cricket board to pay off the debts. The board had to hold player salaries. The national team that won the World T20 in Bangladesh in 2012 was not paid until later. Besides, as there are not enough paid patrons to fill the stadium; free tickets are distributed for matches played at Sooriyawewa. The scale of the stadium is too large for the location. Evidently, there is a huge issue of thinking, particularly in regard to geographic and economic scales and location of development. These are key planning decisions that are non-contextual: the way the airport and stadium are located, they act like counter-magnets.

If these were together, perhaps closer to the city and the port, an economy of scale would have been created. In such a setting, hotels, restaurants, and other infrastructure for these activities would have sprung up. As in other cities, events such as cricket matches would overflow the hotels and restaurants. People visiting Kataragama could stay during the festival season when Kataragama is overcrowded. These are not to be.

\section{Creating Nowhere: New City Center}

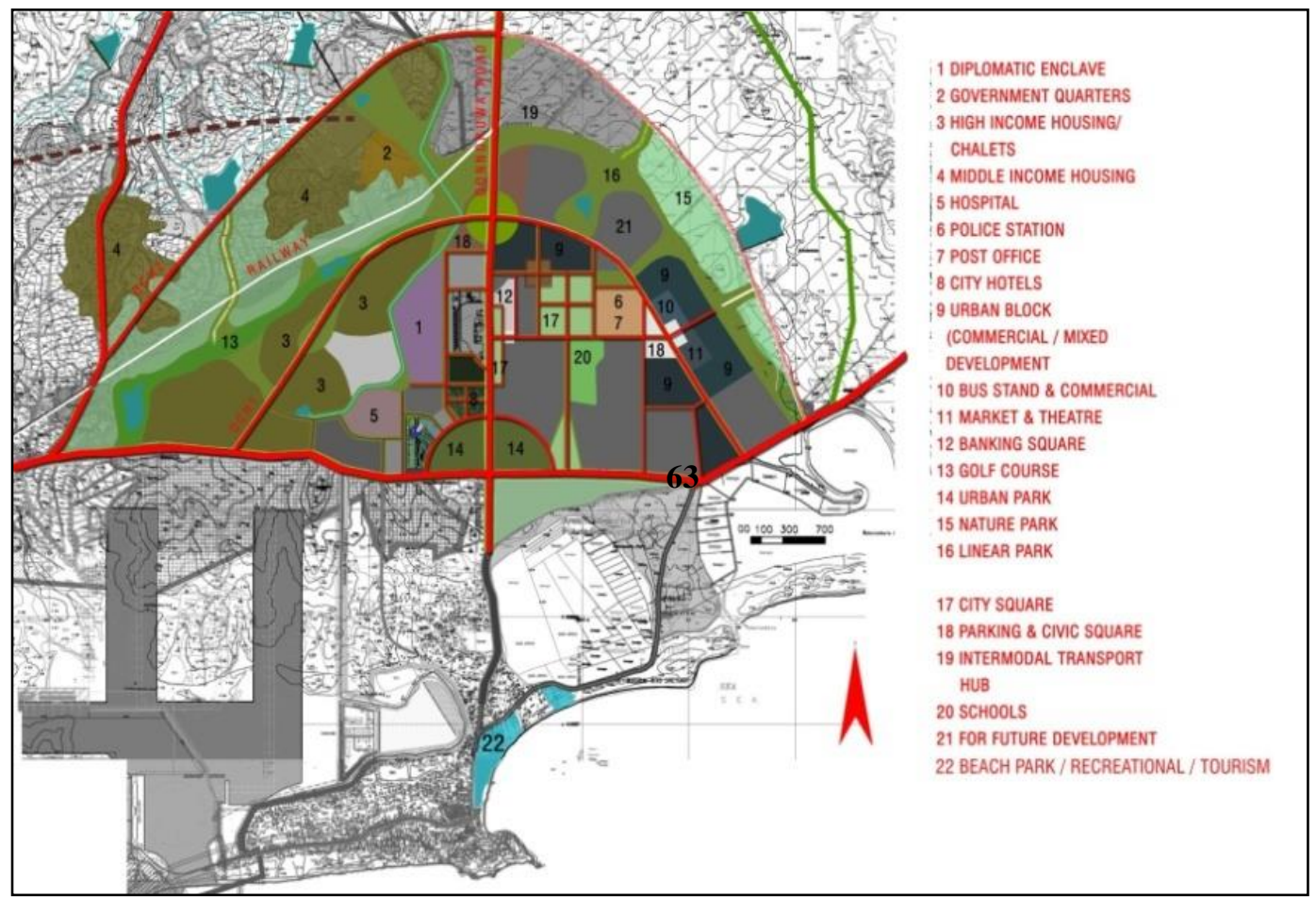

Figure 4: Development Proposals for the New City Center in Siribopura (Source: Urban Development Authority)

According to the Greater Hambantota Development Plan 2030, the new city center is located in Siribopura, about five kilometers on the landside from the present town center. (Figure 4) The new center that is expected to replace the thriving Hambantota town center is an administrative complex. It is located so far away from people and other neighborhoods, it stands like a palace in the jungle. The size and location of the administrative complex confirms the lack of vision and scale. This reminds us of what Nabeel Hamdi (2004, p. 58) so eloquently said: "Places that happen, happen to work; places that are made, don't work." The new development marginalized the Hambantota that people-made, now called the "old town."

The plan is for a new town. In addition to the city center, it is comprised of an industrial area, tourism development along coastal belt, and the extension of southern expressway and southern railway continuing up to Kataragama. The key projects are now complete; the rest are scheduled to be completed in 2030. The population of the new town grew by displacing the tsunami and harbor-project victims instead of by natural growth. Tharanga, a salesman who lives in the present town said, "I was told that I will be given a space for a shop in Siribopura. But I don't understand why I should go there. I have 
enough business here. My customers live here. They are coming to my shop every day. I am happy here."

The city center comprises of city hotels, theaters, a banking square, golf course, urban parks, diplomatic enclave, city square, civic square, transit hub, and the administrative complex. (Figure 4) The location and ordering of these facilities indicate that no one has thought of organizing them into a cohesive urban space.

There is a conflict between the plan and ground conditions. Instead of developing a planning methodology appropriate for the ground conditions (i.e., the people and the environment), the UDA adopted master planning from the West. The plan looks fine on paper, but the flaws began to show during implementation. This caused three problems: (1) wrong projections; (2) conflict between planning and investments patterns, (3) and no town for the current generation.

The town is for one million people. This is clearly an over-projection. It is unclear when and whether such population levels will ever be achieved. The massive roads, a huge secretariat, so far away from the road, indicate over-projections and the scale mix up.

In regard to planning and investments, the plan seems big and is being filled slowly. This is not a new issue. the exact issue has been addressed by Mahaweli planners (MAU) in the 1980s. (Perera 2010) They avoided the towns being a few buildings spread out in the jungle for a generation before the gaps were filled, appropriately densified, and the town became a town. Mahaweli planners created a system of incremental growth, beginning with a small dense urban core. Instead of taking the plan as the product, they considered planning as a process of updating the plan based on the investment pattern and changes on the ground. (Perera 2010) Hambantota planners had not learned from the past experience. As a result, changing the plan of Hambantota is inevitable.

Third, Hambantota lost the old town without a new one replacing it. The current generation will not live long enough to see a new Hambantota, or Siribopura replacing the old town, if that happens. The ambiguity is real: Where would a medical doctor locate her medical practice? Even if we think of a bakery, the issue is the same. As one of Verma's (2003) informants says, "....they did not ask why. They needed to know where [to go]. The where is nowhere recognizable for them." The result is uncertainty and instability. The inhabitants have lost their sense of belonging and ownership of the city, but the power elite and planners do not hold it either.

The authorities now have to fill the plan that is drawn on the ground. The administrative functions are already shifted to the new administrative complex. According to the plan, the businesses, administrative and civic functions, and certain settlements of the old town are to be shifted to the new city. Yet it is a prison in the sense that there is no way to get out even from the administrative complex during the day. Busses do not go there except for at the beginning and end of the workday. Many times buses drop passengers at the highway exit and turn around. People have to walk in the hot sun and there is only so much an umbrella can do to protect a pedestrian as the trees are gone and the vast area of impervious surfaces emits a lot of heat.

In other words, Hambantota is an automobile city like Chandigarh and Naypyitaw. This time-space organization is worse for those who come for official business, unless they use a car. In this, the planners have created a splintered city with the government and bureaucrats in one place and people in another, along with the airport, the cricket stadium, and neighborhoods like Mirrijjiwala, all splintered. Our casual talk with people revealed that the local businessmen were promised land and more opportunities to do their businesses in the new city center. However, what they see is a huge distance and difference between what is provided and what they want, i.e., the planners' abstract space and the lived space the subject wishes to create. (Perera 2016) The proposed city center and its activities do not correspond with the way people wish to live.

The city hotels, urban square, night market, golf course, and city square proposed for the 
new city does not have much meaning to local people. These unfamiliar spaces alienate them. They believe that the target population of the development is not them but an alien community that will be imported to their town in the near future. The locations and the designs after the tsunami were alienating too. (Perera 2016) This type of planning has precedence, (see Logan and Molotch 1987) and the displacement of the poor and ordinary people is what neoliberal planning does. Yet we believe that the planners and designers did not intend to alienate people; it was caused by their ignorance. They did not know any better. The training of the planners is yet to include the planning issues we raise here.

\section{Summoning the Environment}

Hambantota is the most arid area in Sri Lanka. The natural environment is sensitive, but provides a habitat to various animals. A lot of birds live in the area (some seasonally) and there are several bird sanctuaries including Weeravila and Kalametiya. The largest wildlife preserve is in Yala, the far eastern end of the District.

Airports are usually not located near bird habitats as it is dangerous for both the birds and aircrafts during takeoff and landing. The location of the airport was protested by environmentalists and was moved a couple of times, first from Weeravila where there is an air force camp. Yet the second international airport of the country was built in Mattala. As Flyvbjerg (1998) argues: Power has a rationality that rationality does not know. The rumor is that instead of looking for the best place for the airport, the proponents took two environmentally worse locations to compare, so that Mattala is more environmentally friendly.

The city development too disturbed many animal habitats. The obvious was the elephant habitat. Tsunami victims were relocated in a elephant habitat. Elephants used to visit those areas, especially the Suchi school. Yet humans, typically, do not want to live with elephants. They have largely managed to deprive elephants of that part of their habitat.

Planners never raised the breach of rationality and environmental conditions as issues; "environmentally-friendly" was used by them to justify the projects. While presenting the Hambantota plan, the UDA official in-charge of the District called the concentration of projects in several different areas as more environmentally friendly than developing all in one place. This defies the conventional wisdom in planning, which favors compact development as a response to sprawl that is considered bad for the economy, life, and the environment. As scholars, we are interested in UDA Director's questioning of the Western knowledge from local standpoints. Yet there was hardly a science offered to support this argument. A possibility is that it was the Directors' job to justify what a power greater than planning was exercised.

This is not new in countries that have little care for the environment and strong political power. In Singapore, the government wanted to rebut a report that ranked Singapore low in regard to its environmental-friendliness. Then it awarded a huge grant to set up a center for sustainable cities. A main task of this organization was to scientifically justify a position the power had taken. This is a common practice in Sri Lanka where the study of social space and planning is weak and there is hardly any significant planning scholar. As rationality does not know the rationality of power, (Flyvbjerg 1998) the justification may become shabby to those who look for a rationale.

\section{Building Nowhere: The Absence of Urban Design and Concern for People}

Let us begin by appreciating the architecture of the administrative complex. The scale and openness it creates, as well as its aesthetics, work well for Sri Lanka. We did not study enough to determine whether it works well in Hambantota. It seems to work well, but so does post-tsunami structures that could not be readily used by people. (Perera 2016) Yet there are no guidelines for architecture. The site reminds us of Frank Lloyds Wright's response to the prairies in the USA. Wright came up with a horizontal type of architecture that was later called prairie style. Le Corbusier-suggested high-rises in the garden could work too. Yet there is no evident approach to the built environment. The buildings are neither tall, nor horizontal. The 
administrative complex, the convention hall, and the night markets are different kinds of buildings with different scales and styles.

Regardless of how good it is, architecture almost never works in the wrong place. Also the location and scale are crucial for the sense of place. Fetehpur Sikri is one of the most beautiful and functional built environments - a palace complex -in India, but it was abandoned due to being in the wrong place. Planners are highly privileged in that they could designate the best locations. Hambantota has hardly received this service.

The location is also important within the site. Buildings that require grandeur such as the Parliament are usually located at a distance from the entrance, perhaps with a lawn or even a mall (as in the USA) in front that would promote the view from a distance, along an axis, thus enhancing the grandeur. The administrative complex is pushed back, but it is more horizontal and not tall enough to generate any grandeur. In urban areas across the world buildings are located near sidewalks and people's relationship to buildings are intimate; they rub against each other. In new Hambantota, there is hardly any urban character. There are no sidewalks that people could use and people have to walk very far to get from one place to other, perhaps further than in Chicago; also, in the intense sun, from the bus that comes up only to the highway exit. It represents an aesthetically derived design with no consideration for planning which considers function such as walkability, infrastructure such as transportation, and scale.

In Hambantota, the scales are ad hoc. There is a massive convention center on one side of the highway and some structures that look like shacks on the other. The convention center stands alone in the jungle with cows grazing opposite to it. Not even close to Jaipur (India) where cows roam all over the city. This is a total mix up of scales and styles.

The night market is an inadvertent critic of the city. It attempts to familiarize the city to people's scale, but at the wrong location. There is no night market activity in Hambantota; the new location is far away from where people live. On the other side of the road, the convention center emulates much different places like the West or China. One informant asked: "Why is there a huge international convention center right next to where cows graze."

In downtown, there is hardly another building besides the administration building. People have no reason to come except to deal with the government. In this, the highly commercial (old) city of Hambantota has been replaced by a place of government where people have no place. There is no concept of space at people's level: just the land allocation, then building according to the land. In the absence of scale and urban design, highways dominate. The city is sprawled out on flat land. There are no heights, designs, and one cannot see a significant building from another. Hence it lacks visual interconnections between buildings to generate an image. The most prominent is the jungle, then the highways which are very large, contrasting, and imposing on the natural environment. One can see buildings but quite small in scale and spread out. Nowhere is it highlighted by highways. There is no social justice either. People living right next to the expensive highways had no portable water supply until provided by an NGO. The new town has no sense of place.

\section{Archiving the Town: Developing Tourism}

Now that the "old town" is cleansed of its inhabitants, the plan assigns the hypothetically people-less area brought under its control to new businesses. The only new business the regime and the planners knew during that time was tourism. Every coastal town that came under its control after the war, from Mannar to Mullaitivu, were designated tourist sites. The speculation among some people is that a son of the President was into tourism and he was transforming every place under his authority into tourist sites.

Tourism also has its own art and markets. The planners did not help the politicians understand issues, factors of influence, or implications for inhabitants, but instead just became "yes men." The Zoning Plan of Greater Hambantota Development Plan 2030 designated the present town center as a coastal 
tourism zone. (Figure 5) The space that was most central to people's lives were, by this act, effectively pronounced dead. Tourism causes three important changes: First, it makes the locals dispossess the place, making them feel disempowered and underdeveloped. (See Dissanayake this volume) The local residents who live and work in the present town center were informed about the upcoming tourism development projects in their locality at public meetings conducted by local politicians and authorities.

Although the authorities viewed the coastal belt and the scenic beauty of the old town as tourist potential, the locals saw these as their own spaces of play, work, enjoyment, celebration, memory, and life. Sinhala and Muslim communities in Hambantota have a long history of sharing social values and norms. Today, they engage in businesses, their children go to schools across the beach, they relax on the beach, walk along the seashore, and remember their loved ones who got washed away in 2004.

Fishermen fight with the tidal waves day and night to catch fish. The fish market near the fishery harbor, right across from the bus station, is the busiest place at any time of the day. Vegetable and fruit sellers bring their fruits and vegetables close to fish market to find more buyers. These are the local emergences that should be enabled and enhanced. (Perera 2016)

Secondly, tourism transforms the sites into places of consumption for visitors devoid of local interference. A student of the University of Moratuwa from Mannar said that one of the most significant aspects of Mannar is the fish smell. That is how she recognizes that she is home. Tourism developers, she feared, will clean the smell of Mannar and transform it into a foreign place unfamiliar to her. This is precisely what happens to Hambantota town. The planners and politicians did not see and feel the people; they offered the beach and the amenities for the consumption of the tourist.

Thirdly, it creates a power structure that places the tourist above the local. It creates a circumstance in which the tourists enjoy the environment the locals cannot leave. Whatever happens on site, whether begging, or washing clothes, they all become objects of consumption and the Other for the tourist. Tourism is hardly development. In creating tourism, people's places are exoticized, people are objectified, and turned into places of consumption for tourists. In the words of J. Kinciad (2000, p.18-19):

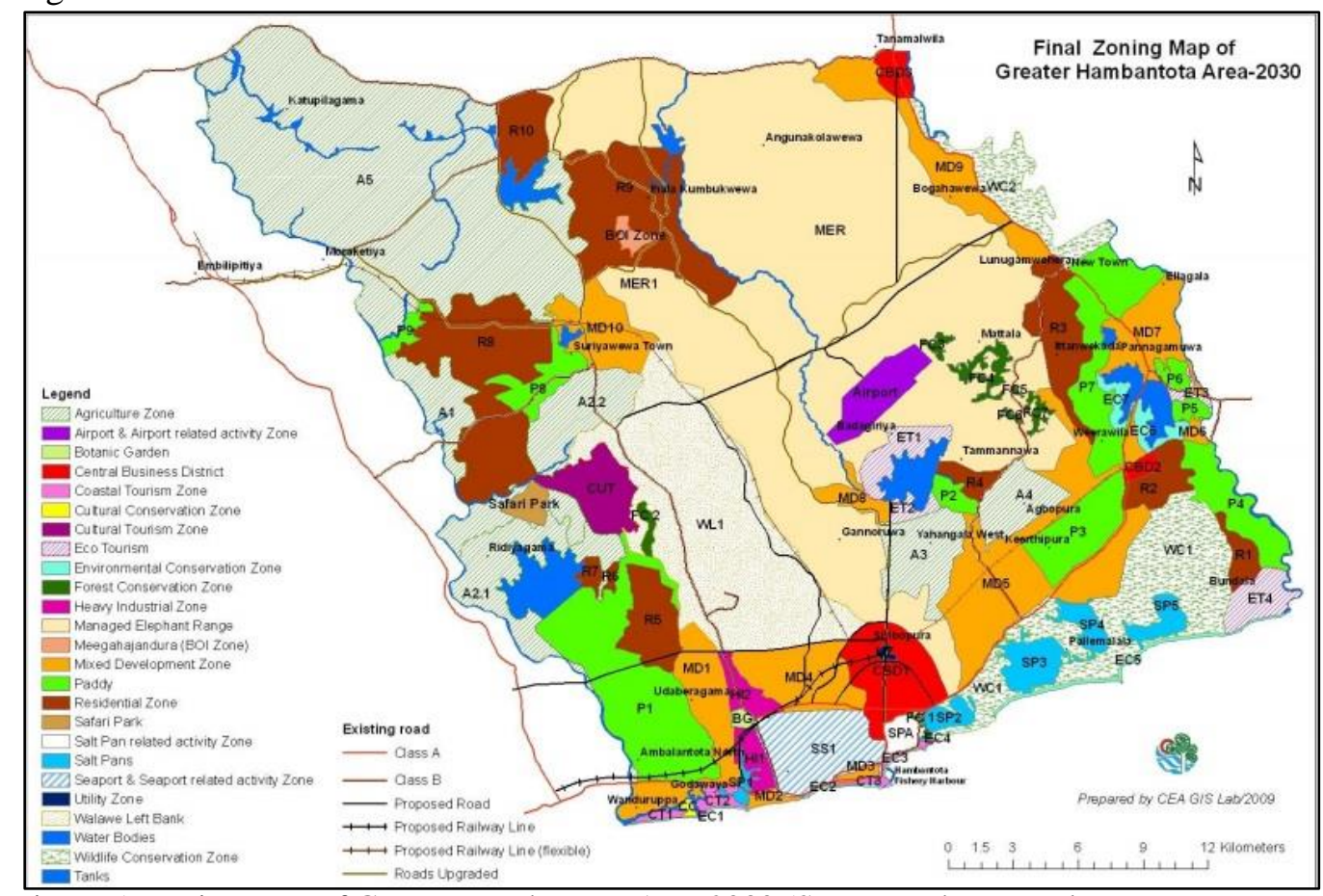

Figure 5: Zoning Map of Greater Hambantota Area 2030 (Source: Urban Development Authority) 
Every native of every place is a potential tourist, and every tourist is a native of somewhere. Every native everywhere lives a life of overwhelming and crushing banality and boredom and desperation and depression, and every deed, good and bad, is an attempt to forget this. Every native would like to find a way out, every native would like a rest, every native would like a tour. But ... most natives in the world [like those in Hambantota] cannot go anywhere. ... They are too poor to go anywhere. They are too poor to escape the reality of their lives; and they are too poor to live properly in the place where they live, which is the very place ... the tourist, wants to go. ... when the natives see ... the tourist, they envy [her/him], they envy [the tourists'] ability to leave [her/his] own banality and boredom, they envy [the tourists'] ability to turn their own banality and boredom into a source of pleasure for the [tourist].

People in the designated tourist area were informed by the authorities that their land will be acquired for tourism related projects and they will be given land in the new town. The planners thus forced their town on the people.

All of a sudden people's lives became uncertain. What was happening around them was far more real than how it sounds in this paper. They were placed in a situation where they had to respond and make decisions immediately. A UDA officer who confessed of evicting people told us that he simply went into areas and demolished houses. He said, "we believed in what we did."

Every local's mind was occupied with one question: When will they ask us to leave? Nazeer, a businessman who lives on Murray Street recounts, "They told us that they will buy our lands. We don't know where to go. I am guessing where I will be given a place. But those places are economically not profitable for me." With the uncertainty and threat of land acquisition, the residents hesitate to improve their dwellings; some do not want to tile their roofs, others do not repair their houses.

\section{Displaced in their Own Place}

The planning profession missed the opportunity for an open evaluation of how well the development was succeeding (or not) in meeting the needs of inhabitants of the town, and rejuvenating the planning profession. Instead, the responsible parties focused on getting favors from the government. They mistook the environment of opportunity as an environment of scarcity. (See Perera, this issue) Planning has thus served the interests of power without understanding its knowledge or logic.

Our interviews indicate that ordinary people of Hambantota felt that they did not fit anywhere in the "mega development" of their town. Even if they get a life, the possible new life in a new environment may not be how they want to live. According to Amartya Sen (1999), development is people's ability to live the life they value as long as they can. Yet, in this stronghold of the then President's political party and family, people had been prepared (taught) to expect benefits; this had raised hope and expectations in most communities.

Yet the projects defamiliarized the environment for the local people, taking away their life. In Nabeel Hamdi's $(2010,44)$ words, "It all belongs to someone other than the people who live there... ." In our words, the inhabitants realize that they are displaced in their own land. There is so much discussion about the displacements caused by natural and other disasters, yet there is not much on state and development induced displacements. The scholars who have addressed such issues include Nishara Fernando who has been addressing the issues of physically displaced due to "development projects" since 2010. (See Fernando 2015)

The planners hardly spent much time with people. When they did, they focused on information categorized and represented through demographics, statistics, maps, and the like. Planners come from various places of the country, mainly from local backgrounds, but what they have learned is a "Western" 
discourse. The planning process is not grounded and the inhabitants and their stories are missing. What it produced was a mixture of suburban buildings and highways in a rural setting. An "externally imposed space." Hambantota people are thus the victims of politics and planning, subjected to slow violence. (Nixon 2013) As it is not dramatic like tsunami, slow violence hardly catches the attention of the media or other significant democratic institutions.

The politicians too are not one; they hardly have one development path (or vision) for Hambantota. Some members of the Rajapaksa family were more concerned about people. On the one hand, politicians were victimized by the plan. According to an official, politicians are trying hard to find investors for the projects proposed by planners. On the other hand, many projects emerge then and there from nowhere, disregarding the plan. As some politicians travel abroad, their cameramen make photos of places. Then the politician asks local planners to build. In this, the government itself undermines its own plans and planners are placed in a difficult spot. The spaces that result from this process are unfamiliar to the inhabitants; perhaps unfamiliar to the power players and planners as well.

This reveals a particular connection between politics and planning in Sri Lanka. The way Hambantota was developed under the Rajapaksa regime is no different to many other development projects elsewhere in the country. In regard to Hambantota, politicians kept making spontaneous decisions far beyond their areas of expertise or knowledge. These decisions belong to different genres and did not go together, like the convention center, the night market, and the cows. As they do not add up, it is not possible to make a plan out of them. Possibly, the politicians involved in decision-making neither knew this fact nor did they care to know planning and development rationalities. Hence, it fell on the shoulders of the experts to both justify and rationalize these. In this, planning was re-defined as a tool of justification of "developments" that result from ad hoc decisions of power players. It was "Decision First; Rationalization Later." (Flyvbjerg 1998, p20)

\section{People's Responses}

The local people both uphold their own values and develop new ones in the new context. For this, they adapt to the changes in the environment and adjust the emerging environment to serve their needs and wants. (Perera 2016) In this, they adopt various strategies to transform spaces to best suit their purposes and interests. This transformative capacity of inhabitants is supported by what James Scott (1985) calls "the weapons of the weak." The indirect, informal, low-profile techniques of resistance followed by relatively powerless people are often the most significant and the most effective over the long run. (Scott 1985) Familiarization, including indigenization, localization, and personalization, are simultaneously forms of questioning, resistance, and adaptation of extant spaces and spatial structures. (Perera, 2007) As elaborated by Perera (2007), the local people's process of creating new hybridized cultural practices and spaces opens up the possibility of redefining and negotiating the space.

Whether they are politically motivated or not, people gradually establish businesses, home gardens, tailoring services, sweet shops expecting that the new city center will provide them opportunities. In Hamdi's (2004, p84) words, people in Hambantota "are trying to create a new meaning for their lives. This is their imagined future. This imagined future is good, because they could be what the imagination conspires them to be rather than what the [authorities] say they have to be."

As Perera (2016, p. 17) highlights in People's Spaces:

Key to the production of lived spaces is the incongruence between available spaces, whether provided and/or imposed, and the people's needs and desires. Lived spaces emerge through the people's process of reconciliation of this conflict. This takes place as negotiation between the needs and aspirations of the subjects and the context of constraints and potential that accommodates, resists, contests, and modifies the context. In this complex process of negotiating space, subjects 
simultaneously adapt themselves to assigned and/or extant subject positions and (abstract) spaces and adjust and restructure these to accommodate their daily activities and socio- cultural practices.

In the case of Hambantota, many kinds of negotiations, adaptations, and responses of people are invisible, not least because of the political situation. However, two kinds of responses are highly visible; those (1) towards opportunities and possibilities and (2) towards threats and uncertainties (somewhat like SWOT analysis). Although the majority of the community feels the threat, a substantive section of the community is anticipating more livelihood opportunities. Few businessmen in the town mentioned that when the tourists and visitors arrive in the city there will be more demand for goods and services. By 2014, certain shops in the town center had begun to display signboards in Chinese. The large number of Chinese workers who work in the construction projects in Hambantota is a target of these businesses.

Meanwhile, another segment of the community feels threatened due to the fact that their land and livelihoods will be taken away by the authorities. These are actions by the authorities to prepare people to serve tourism. Kamala who lives with her family on Target Road states, "We have been sent letters by the government asking us if we would like to convert our home into a guest house for foreigners." Local people are scared to imagine how tourism would impact their lives. As they adapt the surrounding transformations to their liking, and transform their dwellings, they too have to transform themselves to fit within the new (larger) environment.

\section{Local Champions}

As in any other period, many individuals, politicians, and planners saw the great opportunity. Instead of working for their personal benefit, some planners tried to make use of the opportunities to do public good. Such individuals rise up to the occasion. We highlight one such person who is also a joint author of this paper: Hambantota native, planner and politician, (in that order) Mohammed Yehiya.

He grew up in Hambantota town, studied planning at University of Moratuwa, and also became a member of the Municipal Council for the ruling party. He had worked for power and made strong interventions on behalf of the government. Yet he is not there for personal benefit, to make money, or develop some fame for himself at the expense of others. His thinking incorporates people, he has empathy, and learns by doing, thus becoming a better planner and person in the process.

He was one of the first to realize the loss of the approach road and the loss of livelihood in that area. He studied the actual scenarios, drew alternative ways to recover the loss, and made a proposal to the UDA and the Municipal Council. With the help of the Speaker of the Parliament, Chamal Rajapaksa, he continued to fight for an alternative to the road closure. He was largely rejected by the authorities, but the struggle still continues. He uses the Municipality which supposedly represents local people, and other potential support, to fight against the bureaucratic thinking of the UDA. As both insider and outsider, Yehiya has influenced the UDA's thinking.

Using his own private funds, he developed Sippikulama, the abandoned reservoir. $\mathrm{He}$ cleaned it up and introduced fish, turning it into a place for people catch fresh-water fish and recreate. For him, development is neither about transforming people into us, or within our ideals, nor violence against people. Planning is a process that follows people, but as professionals with all the knowledge and professional tools. He knows people and has empathy. He does not plan from far or intend to build and leave. Hence he is routinely questioned and people and request many things. He has opted to live with people and feels the people's pulse.

People also change environments and their habits, but not as violently as the state and the planners wish to do. Yehiya the planner and councilman travels at the speed of people. In this sense, people are not displaced; they become a resource. They are the ones who build it. Then they acquire a sense of 
ownership and develop a sense of place. Unlike violent projects with huge investments, Sippikulama is a people's space that grows slowly As people familiarize the unfamiliar environment created by politicians and planners, he walks with them supporting their dreams and fighting to reclaim the access road and the connection to Mirrijjavila.

\section{Conclusions}

The case of Hambantota was planning in the face of power, but a golden era for planners, policymakers, and developers. The political commitment and the level of investment, two of the most important factors for the implementation of good plans, in just one city, were unprecedented. It is these moments that were capitalized by Mahaweli planners and housing experts in the 1980s. Yet not this time; it resulted in a huge missed opportunity.

The transformation has destroyed the scale and sense of place people, both inhabitants and guests, had for Hambantota. It was a small town of about 10,000 people. As one approaches, the kaludodol and meekiri stores greeted the visitor. The bus stand was right in the middle of the town. One could easily walk to the market, the beach, and the government institutions. For those who stayed, the famous Hambantota Guest House overlooked the beach and the fisheries harbor. For the residents, they could do everything they wanted within walking distance; the beach and the downtown were integrated. The architecture of grandeur and beauty were British, indicating that they are the ones who put this city on the map, but much has not happened since. Yet the city had a sense of place for its inhabitants, and they had a sense of belonging there. The several ethnic and religious groups in the city respected each other; there was hardly a substantial conflict. This is what was lost.

Despite being in an environment of opportunity, the decision makers acted with a mentality of scarcity, with a need to grab something soon, before anyone else. (See Perera, this volume) At the end, planning served the interests of power without ever understanding its knowledge, purpose, or logic. It was also a difficult time. Members of the Rajapaksa regime repeatedly made abrupt, ad hoc decisions that were not compatible enough to add up to a plan or rationality. It was planners' opportunity to develop a more coherent and/or grounded outcome. The planners, especially the Director, justified and rationalized these projects. The planning academy and the professional body hailed. In short, they lost an unprecedented opportunity to develop a great city, critical knowledge, and advance the cause of planning.

\section{Acknowledgments}

We wish to thank the undergraduate (2009/2013 Batch) and graduate students (2013/2015 Batch) of the Department of Town \& Country Planning, University of Moratuwa Sri Lanka who engaged in the Participatory Planning Studio in Hambantota in August, 2013. 


\section{REFERENCES}

Census of Population and Housing Final Report - Southern Province 2012, Retrieved from: http://www.statistics.gov.lk/pophousat/cph2011/Pages/Activities/Reports/Southern.pdf

de Silva, K.M. (1989) A History of Sri Lanka, London: C. Hurst and Co.

Flyvbjerg, B. (1998) Rationality and Power: Democracy in Practice. Chicago, IL: University of Chicago Press.

Hamdi, N. (2010) The Placemaker's Guide to Building Community. London: Routledge.

Kinciad, J. (2000) A Small Place, Farrar, Straus and Giroux.

Fernando, N. (2015). Social Mobility and Class Formation: An Analysis of the Housing Market in Colombo. Paper presented to the CEPA Conference 2015 Nov 27, Colombo, Sri Lanka.

Logan, John R., and Harvey L. Molotch. (1987). Urban Fortunes: The Political Economy of Place. Berkeley: University of California Press.

Nixon, Rob (2013). Slow Violence and the Environmenalism of the Poor. Cambridge, MA: Harvard University Press.

Office of Presidential Secretariat, Sri Lanka. (2008) Poverty Declines in Hambantota, News Line, August 29, 2008, Retrieved from: http://www .priu.gov. .lk/news_update/Current_Affairs/ca200808 /20080829poverty_decline s_in_hambantota_president.html

Perera, N. (2010) “When Planning Ideas Land: Mahaweli’s people-centered approach" in P. Healey and R. Upton (eds.) Crossing Borders: International exchanges and planning practices, New York: Routledge, 141-72.

Perera, N. (2007) Asian Urbanization and Planning: Viewing the Production of Space from the Spaces of Production, Keynote Address at the 19th International Congress of Asian Planning Schools Association, Colombo, Sri Lanka. 27 August 2007.

Perera, N. (2005) "Importing Problems: The impact of a housing ordinance on Colombo," Arab World Geographer 8, 1-2: 61-76.

Ratwatta, C. (2013) History of Hambantota, Mothers who were worried about their Sons and Now. Colombo Telegraph, January 1, 2013. Retrieved from URL: https://www .colombotelegraph.com/index.php/history-of-hambantota-mothers-who-were- worried-about-theirsons-and-now/

Scott, J. (1985) Weapons of the Weak: Everyday Forms of Peasant Resistance. New Haven and London: Yale University Press.

Sen, A. (1999). Development as Freedom. New York: Knopf

Verma, G. D. (2002) Slumming India: A chronicle of slums and their saviours, New Delhi: Penguin Books.

\footnotetext{
${ }^{\mathrm{i}}$ Despite his longer-term familiarity, within the context of this paper, Nihal Perera began collecting data from 2005, with his study of post-tsunami recovery. Shalini Mariyathas also became interested in Hambantota in 2008, but collected targeted data since 2014. Mohammed Yehiya is a Hambantota native who has been a Director of Planning at Hambantota UDA office since 1998.

ii Walker \& Sons Ltd was entrusted with the maintenance of the port and, according to British administrative reports, a number of ships called at the port each month.

${ }^{\text {iii }}$ See Perera (2006) for other significance instances of using colonial geographies.
} 